\title{
Schizosaccharomyces pombe: A Promising Biotechnology for Modulating Wine Composition
}

\author{
Iris Loira * (D), Antonio Morata ${ }^{(D)}$, Felipe Palomero, Carmen González and José Antonio Suárez-Lepe \\ Departamento de Química y Tecnología de Alimentos, Universidad Politécnica de Madrid, Av. Puerta de Hierro, \\ n 2, 28040 Madrid, Spain; antonio.morata@upm.es (A.M.), felipe.palomero@upm.es (F.P.); \\ carmen.gchamorro@upm.es (C.G.); joseantonio.suarez.lepe@upm.es (J.A.S.-L.) \\ * Correspondence: iris.loira@upm.es
}

Received: 26 July 2018; Accepted: 21 August 2018; Published: 23 August 2018

\begin{abstract}
There are numerous yeast species related to wine making, particularly non-Saccharomyces, that deserve special attention due to the great potential they have when it comes to making certain changes in the composition of the wine. Among them, Schizosaccharomyces pombe stands out for its particular metabolism that gives it certain abilities such as regulating the acidity of wine through maloalcoholic fermentation. In addition, this species is characterized by favouring the formation of stable pigments in wine and releasing large quantities of polysaccharides during ageing on lees. Moreover, its urease activity and its competition for malic acid with lactic acid bacteria make it a safety tool by limiting the formation of ethyl carbamate and biogenic amines in wine. However, it also has certain disadvantages such as its low fermentation speed or the development of undesirable flavours and aromas. In this chapter, the main oenological uses of Schizosaccharomyces pombe that have been proposed in recent years will be reviewed and discussed.
\end{abstract}

Keywords: Schizosaccharomyces pombe; oenological uses; maloalcoholic fermentation; stable pigments; wine safety

\section{Origin and Features of Schizosaccharomyces pombe}

Schizosaccharomyces pombe, also known as fission yeast, was discovered by Lindner in 1983 [1]. The cells of this species have a characteristic rod shape with sizes varying between 3-5 $\times 5-24 \mu \mathrm{m}$ (Figure 1). However, immediately after cell division, new cells formed have a more rounded shape due to the turgor pressure [2]. It has a peculiar mode of vegetative reproduction by fission (cross-wall formation) instead of budding, which is more common among yeasts [3]. Cells are separated by the formation of a transverse septum. The spores are formed as a result of sexual reproduction by conjugation of the cells when adverse conditions occur, such as nutrient starvation, and, in the case of S. pombe, between two and four (most often) haploid spores originate in the ascus [4].

Its growth rate is very slow, with a long lag phase and high vitamin requirement. However, it has a low nitrogen requirement [5]. In normal minimal or complex media, the generation time is between 2 and $4 \mathrm{~h}$ [6]. Usually, S. pombe does not develop properly in most culture media due to its aforementioned low growing rate, thus making its isolation from the environment more difficult. A selective-differential medium based on the resistance of $S$. pombe to actidione (antibiotic) and to benzoic acid (inhibitory agent) has been recently proposed to isolate strains of this genus from media with high sugar content [7]. S. pombe strains have been isolated from grape juice, molasses, and kombucha tea $[1,8]$. In addition to glucose, S. pombe can also use glycerol, sucrose, raffinose, and maltose as carbon sources [9]. 


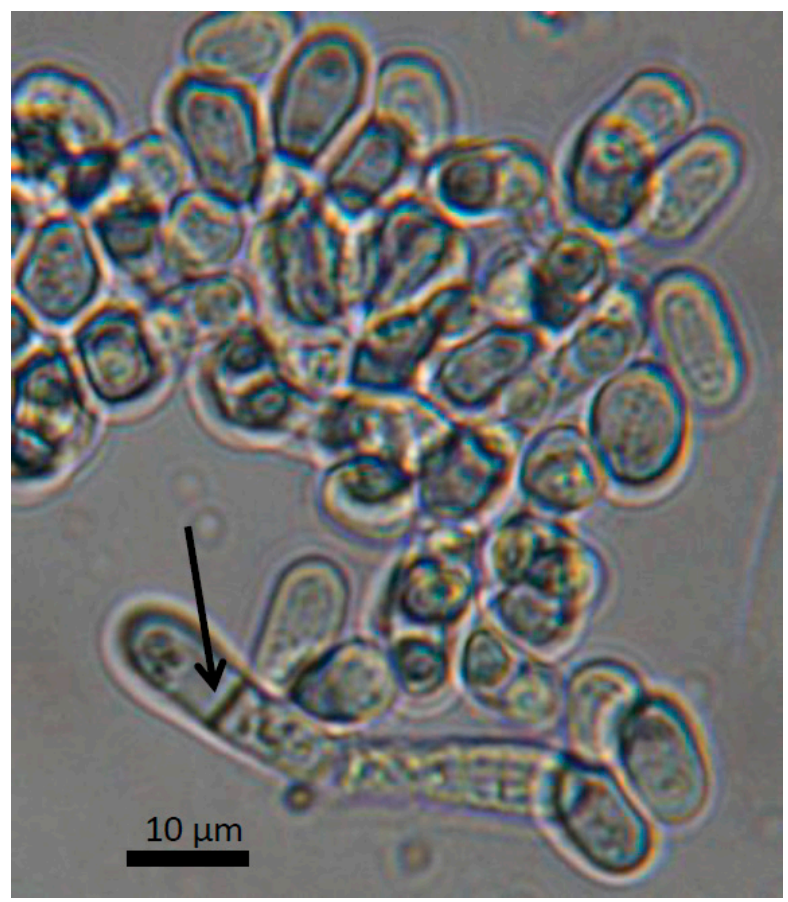

Figure 1. Optical microscope image of Schizosaccharomyces pombe (S. pombe). The transverse septum formed during the asexual reproduction is indicated by an arrow.

Another peculiarity of $S$. pombe is that it can grow in environments with low water activity, that is, it is an osmophilic yeast, and therefore can be found in media with high sugar content [1]. It can also develop in very low $\mathrm{pH}$ environments and in a wide range of temperatures [10]. Moreover, it is somewhat resistant to food preservatives, such as sulphur dioxide, actidione, benzoic acid, and dimethyl dicarbonate $[10,11]$.

Regarding its fermentative performance, it is able to ferment glucose to an alcoholic degree of around $10-15 \% v / v$ ethanol, depending on the yeast strain and the aeration conditions [10]. As already mentioned, the genus Schizosaccharomyces is known for its slow growth rate and excessive production of hydrogen sulphide during fermentation [12]. These two features, together with high volatile acidity, are the main limitations for its use in winemaking. The production of acetic acid is strain-dependent, usually ranging between 0.8 and $1.4 \mathrm{~g} / \mathrm{L}$ [13]. Nevertheless, through the selection of strains and their use in combination with yeasts of the genus Saccharomyces, wines of quality can be obtained from unbalanced musts with high total acidity.

Currently, thanks to recent research that presents new possibilities for their use, non-Saccharomyces yeasts are shedding their bad reputation, and it is possible to find S. pombe yeasts encapsulated in alginate beads being marketed as an alternative to malolactic fermentation or chemical deacidification [14]. An advantage of using these encapsulated yeasts is that they can be removed from the medium at a desired time and, in addition, the same capsules can be reused in several cycles (up to 5 times), although with a slight loss of degrading activity $[15,16]$. Regarding sensory properties, the wines obtained by sequential fermentation of S. pombe and S. cerevisiae were full-bodied, with better structure, balance, and length than the controls made without using this deacidification technique [16].

\section{Wine Acidity Modulation}

Wine acidity is mainly responsible for freshness. After L-tartaric acid, L-malic acid is the second organic acid in wine that contributes significantly to its total acidity. Its average content in wine highly depends on the grape variety and the climate, varying widely between 1 and $10 \mathrm{~g} / \mathrm{L}$ [17]. Reaching an appropriate balance between the sugar content and the total acidity of the wine is fundamental to 
ensure its optimum quality. In addition, excessive amounts of malic acid may cause microbiological instability in wine. These are the two main reasons to modulate wine $\mathrm{pH}$.

The biological deacidification of wine through the use of Schizosaccharomyces pombe has been studied thoroughly $[18,19]$, since its ability to transform malic acid into ethanol and carbon dioxide was discovered in the early 20th century [20]. Thanks to this ability of S. pombe to develop maloalcoholic fermentation (MAF) (Figure 2), it is possible to modulate the $\mathrm{pH}$ of the wine by the consumption of practically all the malic acid present in the must with the corresponding stoichiometric production of ethanol. Unlike S. cerevisiae, in which the malic enzyme is located in the mitochondria (organelle in low numbers and dysfunctional under winemaking conditions), S. pombe has an active transport system for the uptake of extracellular malic acid in addition to a malic enzyme located in the cytosol with a very high substrate affinity [21]. The degree of degradation of malic acid is strain-dependent, normally varying between $75 \%$ and $100 \%$ [5,10]. Issatchenkia orientalis has been also proved to have this strong malic acid degradative metabolism [22,23]. However, this yeast species is only present in small quantities at the beginning of fermentation due to its sensitivity to ethanol [24,25]. Kim, Hong, \& Park (2008) [26] have also reported the effectiveness of using a mixed culture of Issatchenkia orientalis and Saccharomyces cerevisiae to reduce the malic acid content during fermentation. When trying to improve the quality of the wine through the combination in mixed or sequential fermentation of different non-Saccharomyces and Saccharomyces yeast species, it is not only important to know the contribution of each species or strain but also to select the adequate inoculum ratio [27]. Other yeast species, including some Saccharomyces spp. (commercially available strains are generally unable to degrade L-malic acid effectively during fermentation), are able to consume malic acid, but to a lesser extent (usually $<25 \%$ ). Another possibility is to use genetic engineering to improve the ability of $S$. cerevisiae to degrade malic acid, for example, through the incorporation of genes responsible for the transport of malic acid in S. pombe or the malolactic enzyme from Oenococcus oeni [28].

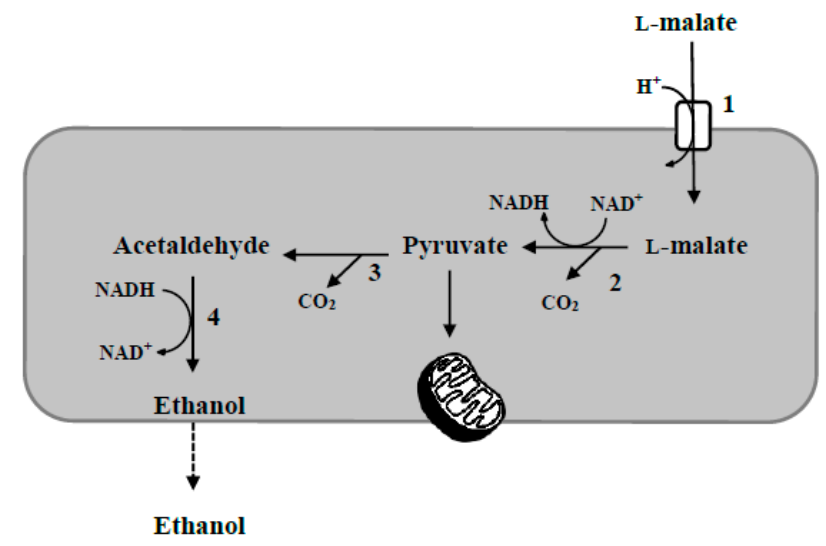

Figure 2. Schematic representation of malic acid degradation by Schizosaccharomyces pombe: maloalcoholic fermentation (MAF) and alternative use of pyruvate in mitochondria for cellular biosynthesis. The enzymes involved in the biochemical transformations of the MAF are the following: 1: malate permease (active transport); 2: malic enzyme (malate decarboxylase); 3: pyruvate decarboxylase; 4: alcohol dehydrogenase. The arrows indicate the direction of the metabolic pathway involved in the transport and degradation of malic acid, identifying the main substrates, products and intermediaries.

Although it has been mentioned on numerous occasions that the aroma produced by the fermentative metabolism of $S$. pombe is not suitable for a quality wine, no particular off-flavour has been described yet. In general, only atypical aroma [19] and a loss in fruity character [29] have been identified by some authors. This could be directly related to the fact that it is a slow fermenting yeast [12]. Sometimes, more than 30 days are necessary to finish the fermentation [29]. Moreover, immobilization techniques have been developed (e.g., alginate beads) in order to avoid negative side 
effects such as high levels of acetic acid and other off-flavours [30]. Following this technique, once the desired malic acid content is reached in the wine thanks to the demalication activity of S. pombe, this yeast is removed, and the fermentation is finished by S. cerevisiae. Snow \& Gallander (1979) [31] suggested that one or two days of $S$. pombe fermentation is adequate to obtain a quality wine like that obtained by $S$. cerevisiae in pure fermentation, avoiding at the same time an excessive deacidification.

In addition to biological deacidification, either by yeast (MAF) or lactic acid bacteria (MLF), there are also other methods to regulate wine acidity such as blending, carbonic maceration, or chemical deacidification using carbonate salts (usually calcium carbonate, $\mathrm{CaCO}_{3}$; potassium carbonate, $\mathrm{K}_{2} \mathrm{CO}_{3}$; and potassium bicarbonate, $\mathrm{KHCO}_{3}$ ) [17].

\section{Influence on Wine Colour}

The colour of the wine is one of the main sensory properties indicative of quality, especially in red wines. It is highly dependent on winemaking technology, especially influenced by the maceration time and the mechanical processes performed during the vinification process (e.g., punch downs, pump overs, délestage...) [32], but the microorganisms used, both yeast and bacteria, also play an important role in the development of the final colour of the wine and its stability.

First, fermentative yeast may influence the colour by modifying the $\mathrm{pH}$. In this sense, oenological yeasts usually produce wines with $\mathrm{pH}$ between 3.2 and 3.8, and under these conditions the anthocyanins tend to have a deep red colour, while the higher the $\mathrm{pH}$, the greater bathochromic shift from red to purple and later to blue [33]. In the case of pure fermentations with S. pombe, pH control would be essential to avoid changes in colour to some extent, because this yeast, as mentioned above, makes a high consumption of malic acid, and therefore the $\mathrm{pH}$ of the wine increases slightly.

Second, through the release of secondary metabolites of fermentation that can react with the grape anthocyanins and thus create more stable forms of colour such as pyranoanthocyanins. The formation of pyranoanthocyanins is of great interest to preserve intense colour in the wine during aging processes, since these pigments that originated during fermentation are much more long-lasting due to their greater stability against $\mathrm{pH}$ changes and discoloration by $\mathrm{SO}_{2}$. The strain effect is quite significant when several $S$. cerevisiae are used, so yeast selection is a useful tool to obtain higher amounts of pyranoanthocyanins during fermentation [34]. Certain strains of S. pombe can lead to improvements in the colour stability of red wine thanks to its high formation of vitisin A and derivatives thereof [35]. It is a direct consequence of its high production of pyruvic acid during fermentation (ranging 150-350 mg/L). The higher values in S. pombe compared to S. cerevisiae ( $<100 \mathrm{mg} / \mathrm{L} ;$ [35]) are probably due to the specific maloalcoholic fermentation pathway in which pyruvate is involved as metabolic intermediate (Figure 2). The amount of pyruvate released by $S$. pombe can favour the formation of 2-4-fold more vitisin A and acetyl vitisin A than S. cerevisiae during the fermentation of red wines (Figure 3). Concerning the production of Vitisin B derivatives, a lower formation of vitisin B is observed with respect to $S$. cerevisiae fermentations [35]. However, the synthesis of vitisin A is more interesting in wines than vitisin B, because the latter is a red-brown pigment (495 nm compared with $515 \mathrm{~nm}$ vitisin A [34], and the hue is less suitable for wine-colour quality).

The enzymatic activity of the yeast is also fundamental, especially regarding the $\beta$-glucosidase and hydroxycinnamate decarboxylase activities. The first enzyme leads to a colour loss, because it catalyses the breakage of the bond between the glucose and the anthocyanidin moieties, also known as anthocyanase activity [36]. These same authors reported that no $\beta$-glucosidase activity was detected for the four strains of $S$. pombe that were evaluated. Some strains of $S$. pombe have also shown the ability to transform the hydroxycinnamic acids present in the must (e.g., $p$-coumaric, caffeic and ferulic acids) into vinyl phenols that can condense with monomeric anthocyanins to form vinylphenolic pyranoanthocyanins $[37,38]$. These pyranoanthocyanins display same enological properties as vitisins concerning to their stability. Vinyl phenols are formed during fermentation by yeasts with hydroxycinnamate decarboxylase activity (HCDA). It is possible to find this activity in many non-Saccharomyces strains [39]. It has been observed that some strains of S. pombe exhibit 
a strong HCDA that can increase the formation of malvidin-3-O-glucoside-4-vinylphenol and malvidin-3-O-(6'-p-coumaroylglucoside)-4-vinylphenol by $10-30 \%$ compared with $S$. cerevisiae strains selected for their performance in this activity [35]. Therefore, the selection and use of S. pombe in fermentation is a powerful tool for increasing the formation of stable pyranoanthocyanins, including vitisin A derivatives and vinylphenolic pyranoanthocyanins.

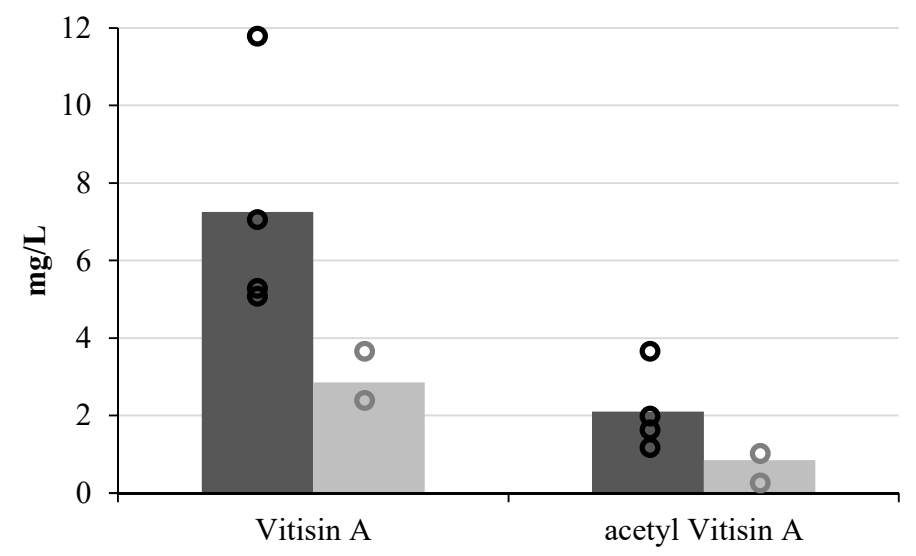

Figure 3. Formation of vitisin A and acetyl vitisin A during the fermentation with S. pombe (4 strains; dark grey bars) and Saccharomyces cerevisiae (S. cerevisiae) (2 strains; light grey bars). Bars are average concentrations, dots are single values for each strain (Adapted from [35]).

Polymeric pigments are formed by chemical condensation between grape anthocyanins and other flavanols in a slow process during ageing that is affected by precursor contents, $\mathrm{pH}$, and temperature and oxygen levels. Some of these pigments have red-orange colour, but others can absorb at $540 \mathrm{~nm}$ or higher wavelength showing red-bluish colours. It has been observed that some yeasts are able to promote the formation of these pigments more quickly during fermentation [40,41]. S. pombe has shown that high performance increases the formation of polymeric pigments derived from malvidin-3-O-glucoside and catechin or procyanidin B2 [40]. On average, increments in the polymeric pigments can vary widely between 35.9 and $88.0 \%$ with respect to their counterparts with $S$. cerevisiae, depending on the par of yeast species used in the sequential fermentation [40]. Yeast influence can be produced by the fermentative release of acetaldehyde, which can favour the formation of ethyl linked dimers [42]. Furthermore, some synergic effects were seen when $S$. pombe was used in sequential fermentations with Lachancea thermotolerans [40].

Finally, yeasts are able to trap significant amounts of pigments in their cell wall [43,44]. During fermentation, yeast cell walls can reach a specific surface of $10 \mathrm{~m}^{2} / \mathrm{L}$ of must when population is $10^{8}-10^{9} \mathrm{CFU} / \mathrm{mL}$ [43], and cell wall adsorbed anthocyanins can represent $1.6-6 \%$ of wine content reaching $28 \%$ for some derivatives in some yeast strains [44]. The number of anthocyanins adsorbed into yeast cell walls can be evaluated using plating media dosed with grape anthocyanins [45]. Alternatively, and with higher precision, it is possible to recover adsorbed anthocyanins from yeast cell walls and analyse the extracts by LC-DAD or LC-DAD-MS [43]. When adsorption of anthocyanins was studied in non-Saccharomyces cell walls, a differential adsorption was observed according to yeast species but also according to strain. In a comparative view of adsorption in the plating system with anthocyanins added to the agar formulation, it is possible to see a medium adsorption capacity for S. pombe (strain 938) compared with other species with high adsorption (L. thermotolerans, formerly Kluyveromyces thermotolerans) or the low adsorption of Metschnikowia pulcherrima (Figure 4). 


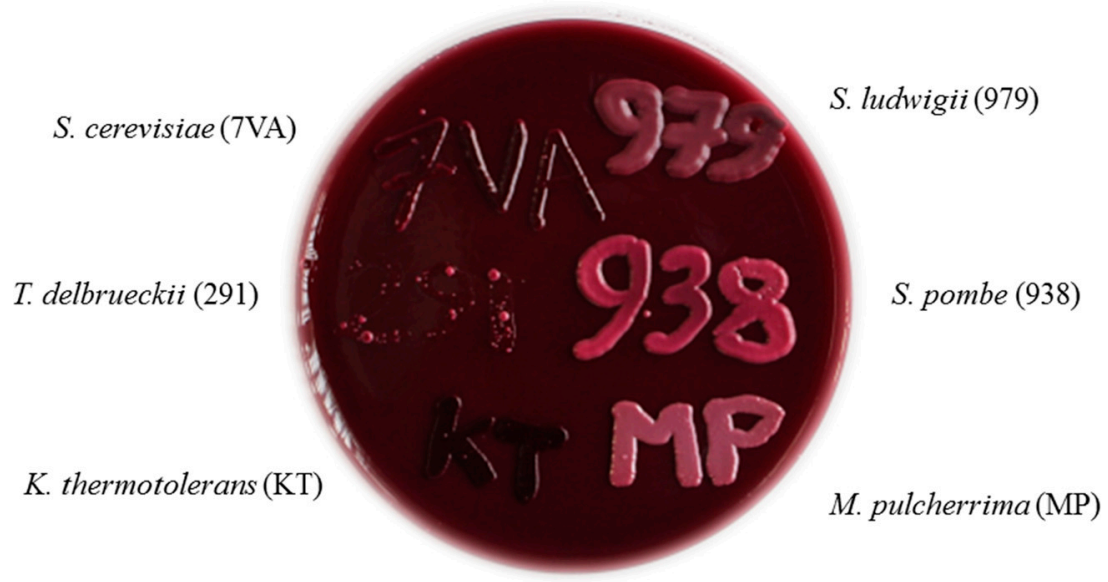

Figure 4. Adsorption of grape anthocyanins in yeast cell walls (Saccharomyces and non-Saccharomyces) during growth in a specific plating media containing pigments.

The protective effect of ageing on lees (AOL) on wine oxidation by the release of reductive compounds from yeast structures such as glutathione can also produce some preservation on wine anthocyanins. The high release of cell wall compounds from S. pombe during ageing on lees [46] can favour and enhance this protective effect, thus better preserving wine colour.

\section{Large Release of Polysaccharides during Ageing on Lees}

As previously stated, Schizosaccharomyces yeast genus physiology and metabolism present some peculiarities. S. pombe cell wall carbohydrate composition and distribution of polysaccharides and other wall constituents is quite particular, which is something which should not be surprising bearing in mind we are dealing with an osmophilic yeast that reproduces itself/asexually by binary fission thanks to the formation of a wall, from centre to centre of the cell (Figure 1; [47,48]). Early in the seventies, some authors studied the structure and composition of their cell walls [49]. Indeed, the qualitative composition and formation of cell wall polysaccharides can vary greatly among yeasts, and these differences are useful for taxonomic classification purposes [50,51]. Later electron microscopy studies after enzyme treatments, aiming to deeply understand the molecular organization of $S$. pombe cell walls, highlighted the presence of galacto-mannoproteins in the outer layer of the cell wall as its main qualitative discriminating feature [52]. A comparative illustration of the cell walls of Schizosaccharomyces pombe and Saccharomyces cerevisiae based on these studies permits the observation of these qualitative differences among these species [46]. Besides these special features of S. pombe, a simple optical microscopy lets us appreciate its thickened cell walls. That significant thickness (average: 10-200 $\mathrm{nm} \mathrm{[2,53])} \mathrm{and} \mathrm{the} \mathrm{previously} \mathrm{mentioned} \mathrm{particular} \mathrm{molecular} \mathrm{organization} \mathrm{of}$ biopolymers in S. pombe cell walls give them structural strength enough to resist high osmotic pressures.

Ageing over lees has been traditionally used to produce white wines [54,55], but red wines can undergo this process too, and its repercussion in the sensory profile of the wine is nowadays better understood. The autolytic release of yeast cell wall polysaccharides in wine making and their contribution to aspects such as mouthfeel and tactile properties, wine aroma, body, and physicochemical stability has been widely studied, discussed, and demonstrated [56]. In particular, mannoproteins act as colloidal stabilizers, having a positive effect on tartrate stability [57], decreasing tannin aggregation and precipitation [58], and protecting wine form protein haze in white wines [59,60]. The production and release of these macromolecules depends on the yeast strain, and according to Vidal et al. in 2003 [61], they can reach up to $35 \%$ of total polysaccharides in wine.

Ageing over lees of red wines has been usually described as a technique that helps to stabilize colour and modulate astringency. Several interactions between yeast lees and phenols could take place simultaneously, and factors such as yeast lees reactivity towards oxygen $[62,63]$, the strain capacity to 
absorb anthocyanins $[43,64,65]$, or the presence of $\beta$-glucosidase activity explain why contradictory results and hypotheses can be easily found in the literature.

The autolytic release of polysaccharides by Schizosaccharomyces pombe was studied for the first time in synthetic media by Palomero et al., in 2009 [46]. From the first moment, results showed a high quantity of cell wall polysaccharides. At 28 days, both osmophilic yeasts Schizosaccharomyces pombe and Saccharomycodes ludwigii released cell-wall fragments in concentrations more than ten times greater than those produced by the Saccharomyces and Pichia strains studied. Two months into the over lees ageing process, the polysaccharide concentrations of the osmophilic yeast autolysates were those that would be reached at six or seven months by Saccharomyces. This rapid release could entail an important competitive advantage for wineries due to the reduction of ageing periods. Besides this, an early elution peak was observed in the HPLC-RI chromatograms corresponding to biopolymers of over $788 \mathrm{kDa}$. These fragments are therefore larger than most of those observed from Saccharomyces and should be studied in order to understand its potential oenological interest to modulate astringency, improve palatability, and preserve colour [46]. Domizio et al. in 2017 [66] have recently found larger polysaccharide molecules in earlier peaks by HPLC-RI when studying and characterizing S. pombe polysaccharides but were not detected in the chromatograms of the corresponding S. japonicus. These authors obtained similar results when studying the release of polysaccharides during alcoholic fermentation. They conclude that all the Schizosaccharomyces strains studied released a quantity of polysaccharides approximately 3 to 7 times higher than that released by a commercial Saccharomyces cerevisiae. Subsequent studies have obtained similar results, underlining the polysaccharide overproduction of yeast belonging to the Schizosaccharomyces genus [67].

\section{Bio-Tool for Ensuring Wine Safety}

The metabolic characteristics of $S$. pombe make it the ideal bio-tool to reduce the content of certain unwanted compounds in musts and wines, either because they are responsible for long-term microbiological instability, because they adversely affect the sensory quality of the wine, or because they can lead to toxic compounds [10]. Some examples of compounds that can be controlled by S. pombe are malic acid, biogenic amines, gluconic acid, and ethyl carbamate.

The ability of $S$. pombe to metabolize malic acid was previously discussed (see section "Wine $\mathrm{pH}$ modulation" above). This organic acid is not only a source of microbiological instability in the wine but also contributes a hard and green acidity.

Biogenic amines may pose health problems. An advantage of using S. pombe instead of lactic acid bacteria (LAB) for the elimination of malic acid is that this yeast does not promote the formation of biogenic amines, a health issue associated with the traditional malolactic fermentation performed by LAB $[68,69]$. It is worth mentioning that, unlike wild malolactic bacteria, the available commercial LABs have been selected according to the criterion of low production of biogenic amines and ethyl carbamate. The combination of Lachancea thermotolerans and S. pombe for the sequential fermentation of a red must with high $\mathrm{pH}$ has been shown to be effective in the control of the biogenic amines formation, with a reduction in the concentration of histamine of up to four times with respect to the same grape must that underwent a malolactic fermentation [68]. In addition, the organoleptic quality of the wine was not compromised by the employment of two non-Saccharomyces yeasts for the fermentation.

Gluconic acid decreases the microbiological stability of the wine, since LAB can metabolize it, increasing the acetic acid levels and, therefore, damaging the quality of the wine [70]. High contents of this acid are related to the development of the fungal disease called gray rot. It has been shown that $S$. pombe can metabolize gluconic acid and in this way favour the biological aging of wines by preventing the development of LAB [71].

Despite belonging to the ascomycetes group, S. pombe exhibits a strong urease activity [72]. Urease catalyses the hydrolysis of urea into ammonia and carbamate; the latter product is spontaneously hydrolysed to carbonic acid and ammonia under oenological conditions. Ethyl carbamate is a well-known carcinogen produced during fermentation and ageing, and urea is one 
of its precursors [73]. The safety limits established for ethyl carbamate in wines widely vary between 15 and $60 \mu \mathrm{g} / \mathrm{L}$ depending on the country and the type of wine, with dessert wines constituting the upper limit. Therefore, fermenting with S. pombe may prevent ethyl carbamate production.

\section{Sparkling Wines and Other Fermented Beverages (Ice Wines, Beers)}

In the winemaking of sparkling wines, there is a second fermentation in bottle in which it is necessary to use a yeast that can ferment in the presence of around $10 \% v / v$ ethanol (base wine). In addition to complying with this requirement, $S$. pombe can be an interesting species for this process due to its high release rate of polysaccharides during ageing on lees [74]. The higher the polysaccharide content in the wine, the better the mouth-feel sensations (reducing astringency, enhancing sweetness and roundness) and the aromatic persistence and quality [75]. It also has a protective effect on wine colour.

Moreover, the employment of S. pombe for the second fermentation and ageing on lees of sparkling wines production was suggested to obtain differentiation [76]. With the use of S. pombe, red sparkling wines with higher pyranoanthocyanin concentrations and higher colour intensity were obtained [76]. Concerning the sensory evaluation, both white and red wines were rated as high-quality without notable differences in relation to the control of $S$. cerevisiae in taste characters but with some differences at the aromatic and visual level. S. pombe seems more suitable for winemaking in red than in white, partially losing the fruity and floral character in the latter. The red sparkling wines made with S. pombe were the ones that obtained the highest score for the colour intensity and aromatic intensity. Although the herbal, buttery, and yeasty notes stood out significantly, the wines had a good balance on the nose, and no aromatic defects were perceived. However, these results come from a single strain of $S$. pombe (selected for its good fermentative behaviour); it would certainly be interesting to try new strains.

S. pombe was also tested as yeast responsible for the bottle fermentation in brewing [13]. The amount of sugar metabolized in beer production is markedly lower than in wine and, therefore, the amount of acetic acid synthesized by S. pombe should also be lower. S. pombe also has potential application in the production of ice wines, especially when it comes to obtaining wines with a better balance of acidity [77].

\section{Conclusions}

Schizosaccharomyces pombe is a useful tool for total or partial deacidification of grape musts and achieves high quality in the final wine when immobilization techniques are used. This species has shown promising results regarding the production of stable colour forms, thereby ensuring colour preservation in aged wines. Its use in winemaking can also prevent potential health risks associated with the metabolism of the lactic acid bacteria responsible for malolactic fermentation. As a general conclusion, due to its great resistance to $\mathrm{pH}$, temperature, and preservatives, and its ability to ferment in media with high sugar content, $S$. pombe is a strain of great versatility with potential utility not only in oenology but also in other sectors of the food industry.

Author Contributions: I.L.: literature review, writing, and editing; A.M.: literature review, writing, and images design; F.P.: literature review and writing; C.G.: critical reading; and J.A.S.-L.: critical reading.

Conflicts of Interest: The authors declare no conflicts of interest.

\section{References}

1. Kurtzman, C.P.; Fell, J.W.; Boekhout, T. The Yeasts: A Taxonomic Study; Elsevier: London, UK, 2010.

2. Atilgan, E.; Magidson, V.; Khodjakov, A.; Chang, F. Morphogenesis of the fission yeast cell through cell wall expansion. Curr. Biol. 2015, 25, 2150-2157. [CrossRef] [PubMed]

3. Vaughan Martini, A. Evaluation of phylogenetic relationships among fission yeast by nDNA/nDNA reassociation and conventional taxonomic criteria. Yeast 1991, 7, 73-78. [CrossRef] [PubMed] 
4. Krapp, A.; Del Rosario, E.C.; Simanis, V. The role of Schizosaccharomyces pombe dma1 in spore formation during meiosis. J. Cell Sci. 2010, 123, 3284-3293. [CrossRef] [PubMed]

5. Benito, S.; Palomero, F.; Morata, A.; Calderón, F.; Suárez-Lepe, J.A. New applications for Schizosaccharomyces pombe in the alcoholic fermentation of red wines. Int. J. Food Sci. Technol. 2012, 47, 2101-2108. [CrossRef]

6. Moreno, S.; Klar, A.; Nurse, P. Molecular genetic analysis of fission yeast Schizosaccharomyces pombe. Methods Enzymol. 1991, 194, 795-823. [CrossRef] [PubMed]

7. Benito, S.; Galvez, L.; Palomero, F.; Calderón, F.; Morata, A.; Palmero, D.; Suárez-Lepe, J.A. Schizosaccharomyces selective differential media. Afr. J. Microbiol. Res. 2013, 7, 3026-3036. [CrossRef]

8. Teoh, A.L.; Heard, G.; Cox, J. Yeast ecology of Kombucha fermentation. Int. J. Food Microbiol. 2004, 95, 119-126. [CrossRef] [PubMed]

9. Petersen, J.; Russell, P. Growth and the environment of Schizosaccharomyces pombe. Cold Spring Harb. Protoc. 2016, 3, 210-226. [CrossRef]

10. Suárez-Lepe, J.A.; Palomero, F.; Benito, S.; Calderón, F.; Morata, A. Oenological versatility of Schizosaccharomyces spp. Eur. Food Res. Technol. 2012, 235, 375-383. [CrossRef]

11. Escott, C.; Loira, I.; Morata, A.; Bañuelos, M.A.; Suárez-Lepe, J.A. Wine spoilage yeasts: Control strategy. In Yeast-Industrial Applications; InTech: London, UK, 2017; pp. 89-116.

12. Rankine, B.C. The importance of yeasts in determining the composition and quality of wines. Vitis 1968, 7, 22-49.

13. Callejo, M.J.; González, C.; Morata, A. Use of non-Saccharomyces yeasts in bottle fermentation of aged beers. In Brewing Technology; InTech: London, UK, 2017; pp. 101-119.

14. Proenol ProMalic. Biological Deacidification of Musts and Wines. Available online: https://www.proenol. $\mathrm{com} /$ web/produtos/leveduras-encapsuladas/promalic-detail (accessed on 22 August 2018).

15. Ramon-Portugal, F.; Silva, S.; Taillandier, P.; Strehaiano, P. Inmovilización de Levaduras. Usos Enológicos Actuales. Vinidea.net., 2003; pp. 1-8. Available online: https://www.infowine.com/intranet/libretti/ libretto922-01-1.pdf (accessed on 22 August 2018).

16. Silva, S.; Ramón-Portugal, F.; Andrade, P.; Abreu, S.; de Fatima Texeira, M.; Strehaiano, P. Malic acid consumption by dry immobilized cells of Schizosaccharomyces pombe. Am. J. Enol. Vitic. 2003, 54, 50-55.

17. Su, J.; Wang, T.; Wang, Y.; Li, Y.-Y.; Li, H. The use of lactic acid-producing, malic acid-producing, or malic acid-degrading yeast strains for acidity adjustment in the wine industry. Appl. Microbiol. Biotechnol. 2014, 98, 2395-2413. [CrossRef] [PubMed]

18. Rankine, B.C. Decomposition of L-malic acid by wine yeasts. J. Sci. Food Agric. 1966, 17, 312-316. [CrossRef] [PubMed]

19. Gallander, J.F. Deacidification of eastern table wines with Schizosaccharomyces pombe. Am. J. Enol. Vitic. 1977, $28,65-68$.

20. Kluyver, A.J. Biochemische Suikerbepalingen. Ph.D. Thesis, Delft University of Technology, Delft, The Netherlands, January 1914.

21. Volschenk, H.; van Vuuren, H.J.J.; Viljoen-Bloom, M. Malo-ethanolic fermentation in Saccharomyces and Schizosaccharomyces. Curr. Genet. 2003, 43, 379-391. [CrossRef] [PubMed]

22. Seo, S.-H.; Rhee, C.-H.; Park, H.-D. Degradation of malic acid by Issatchenkia orientalis KMBL 5774, an acidophilic yeast strain isolated from Korean grape wine pomace. J. Microbiol. 2007, 45, 521-527. [PubMed]

23. Hong, S.K.; Lee, H.J.; Park, H.J.; Hong, Y.A.; Rhee, I.K.; Lee, W.H.; Choi, S.W.; Lee, O.S.; Park, H.D. Degradation of malic acid in wine by immobilized Issatchenkia orientalis cells with oriental oak charcoal and alginate. Lett. Appl. Microbiol. 2010, 50, 522-529. [CrossRef] [PubMed]

24. Clemente-Jimenez, J.M.; Mingorance-Cazorla, L.; Martínez-Rodríguez, S.; Las Heras-Vázquez, F.J.; Rodríguez-Vico, F. Molecular characterization and oenological properties of wine yeasts isolated during spontaneous fermentation of six varieties of grape must. Food Microbiol. 2004, 21, 149-155. [CrossRef]

25. Zott, K.; Claisse, O.; Lucas, P.; Coulon, J.; Lonvaud-Funel, A.; Masneuf-Pomarede, I. Characterization of the yeast ecosystem in grape must and wine using real-time PCR. Food Microbiol. 2010, 27, 559-567. [CrossRef] [PubMed]

26. Kim, D.-H.; Hong, Y.-A.; Park, H.-D. Co-fermentation of grape must by Issatchenkia orientalis and Saccharomyces cerevisiae reduces the malic acid content in wine. Biotechnol. Lett. 2008, 30, 1633-1638. [CrossRef] [PubMed] 
27. Comitini, F.; Gobbi, M.; Domizio, P.; Romani, C.; Lencioni, L.; Mannazzu, I.; Ciani, M. Selected non-Saccharomyces wine yeasts in controlled multistarter fermentations with Saccharomyces cerevisiae. Food Microbiol. 2011, 28, 873-882. [CrossRef] [PubMed]

28. Volschenk, H.; van Vuuren, H.J.J.; Viljoen-Bloom, M. Malic acid in wine: Origin, function and metabolism during vinification. S. Afr. J. Enol. Vitic. 2006, 27, 123-136. [CrossRef]

29. Redzepovic, S.; Orlic, S.; Majdak, A.; Kozina, B.; Volschenk, H.; Viljoen-Bloom, M. Differential malic acid degradation by selected strains of Saccharomyces during alcoholic fermentation. Int. J. Food Microbiol. 2003, 83, 49-61. [CrossRef]

30. Yokotsuka, K.; Otaki, A.; Naitoh, A.; Tanaka, H. Controlled simultaneous deacidification and alcohol fermentation of a high-acid grape must using two immobilized yeasts, Schizosaccharomyces pombe and Saccharomyces cerevisiae. Am. J. Enol. Vitic. 1993, 44, 371-377.

31. Snow, P.G.; Gallander, J.F. Deacidification of white table wines through partial fermentation with Schizosaccharomyces pombe. Am. J. Enol. Vitic. 1979, 30, 45-48.

32. Morata, A.; González, C.; Tesfaye, W.; Loira, I.; Suárez-Lepe, J.A. Maceration and fermentation. New technologies to increase extraction. In Red Wine Technology; Morata, A., Ed.; Elsevier-Academic Press: Cambridge, MA, USA, 2018.

33. Khoo, H.E.; Azlan, A.; Tang, S.T.; Lim, S.M. Anthocyanidins and anthocyanins: Colored pigments as food, pharmaceutical ingredients, and the potential health benefits. Food Nutr. Res. 2017, 61, 1361779. [CrossRef] [PubMed]

34. Morata, A.; Loira, I.; Suárez-Lepe, J.A. Influence of yeasts in wine colour. In Grape and Wine Biotechnology; Morata, A., Loira, I., Eds.; InTech: London, UK, 2016; pp. 288-289.

35. Morata, A.; Benito, S.; Loira, I.; Palomero, F.; González, M.C.; Suárez-Lepe, J.A. Formation of pyranoanthocyanins by Schizosaccharomyces pombe during the fermentation of red must. Int. J. Food Microbiol. 2012, 159, 47-53. [CrossRef] [PubMed]

36. Manzanares, P.; Rojas, V.; Genovés, S.; Vallés, S. A preliminary search for anthocyanin- $\beta$-D-glucosidase activity in non-Saccharomyces wine yeasts. Int. J. Food Sci. Technol. 2000, 35, 95-103. [CrossRef]

37. Morata, A.; Gómez-Cordovés, M.C.; Calderón, F.; Suárez, J.A. Effects of pH, temperature and $\mathrm{SO}_{2}$ on the formation of pyranoanthocyanins during red wine fermentation with two species of Saccharomyces. Int. J. Food Microbiol. 2006, 106, 123-129. [CrossRef] [PubMed]

38. Morata, A.; González, C.; Suárez-Lepe, J.A. Formation of vinylphenolic pyranoanthocyanins by selected yeasts fermenting red grape musts supplemented with hydroxycinnamic acids. Int. J. Food Microbiol. 2007, 116, 144-152. [CrossRef] [PubMed]

39. Suárez-Lepe, J.A.; Morata, A. Capítulo IV.-El atractivo visual del color del vino tinto: Implicaciones microbiológicas en nuevas formas estables y pérdidas de antocianos durante la fermentación. In Levaduras Para Vinificación en tinto [Yeasts for Red Winemaking]; Tecnovino: Bilbao, Spain, 2015.

40. Escott, C.; Del Fresno, J.M.; Loira, I.; Morata, A.; Tesfaye, W.; González, M.D.C.; Suárez-Lepe, J.A. Formation of polymeric pigments in red wines through sequential fermentation of flavanol-enriched musts with non-Saccharomyces yeasts. Food Chem. 2018, 239. [CrossRef] [PubMed]

41. Escott, C.; Morata, A.; Loira, I.; Tesfaye, W.; Suarez-Lepe, J.A. Characterization of polymeric pigments and pyranoanthocyanins formed in microfermentations of non-Saccharomyces yeasts. J. Appl. Microbiol. 2016, 121, 1346-1356. [CrossRef] [PubMed]

42. Dallas, C.; Ricardo-da-Silva, J.M.; Laureano, O. Products formed in model wine solutions involving anthocyanins, procyanidin B2, and acetaldehyde. J. Agric. Food Chem. 1996, 44, 2402-2407. [CrossRef]

43. Morata, A.; Gómez-Cordovés, M.C.; Suberviola, J.; Bartolomé, B.; Colomo, B.; Suárez, J.A. Adsorption of anthocyanins by yeast cell walls during the fermentation of red wines. J. Agric. Food Chem. 2003, 51, 4084-4088. [CrossRef] [PubMed]

44. Morata, A.; Gómez-Cordovés, M.C.; Colomo, B.; Suárez, J.A. Cell wall anthocyanin adsorption by different Saccharomyces strains during the fermentation of Vitis vinifera L. cv Graciano grapes. Eur. Food Res. Technol. 2005, 220, 341-346. [CrossRef]

45. Caridi, A.; Sidari, R.; Kraková, L.; Kuchta, T.; Pangallo, D. Assessment of color adsorption by yeast using grape skin agar and impact on red wine color. OENO One 2015, 49, 195-203. [CrossRef]

46. Palomero, F.; Morata, A.; Benito, S.; Calderón, F.; Suárez-Lepe, J.A. New genera of yeasts for over-lees aging of red wine. Food Chem. 2009, 112, 432-441. [CrossRef] 
47. Kreger-Van Rij, N.J.W. The Yeasts: A Taxonomic Study; Elsevier: New York, NY, USA, 1984.

48. Lodder, J. The Yeasts; a Taxonomic Study; North-Holland Pub. Co.: Amsterdam, The Netherlands, 1970.

49. Manners, D.J.; Meyer, M.T. The molecular structures of some glucans from the cell walls of Schizosaccharomyces pombe. Carbohydr. Res. 1977, 57, 189-203. [CrossRef]

50. Bartnicki-Garcia, S. Cell Wall Chemistry, Morphogenesis, and Taxonomy of Fungi. Annu. Rev. Microbiol. 1968, 22, 87-108. [CrossRef] [PubMed]

51. Weijman, A.C.M.; Golubev, W.I. Carbohydrate patterns and taxonomy of yeast and yeast-like fungi. In The Expanding Realm of Yeast-Like Fungi; Hoong, G.S., Smith, M.T., Weijman, A.C.M., Eds.; Elsevier: Amsterdam, The Netherlands, 1987; pp. 361-371.

52. Kopecká, M.; Fleet, G.H.; Phaff, H.J. Ultrastructure of the Cell Wall of Schizosaccharomyces pombe Following Treatment with Various Glucanases. J. Struct. Biol. 1995, 114, 140-152. [CrossRef] [PubMed]

53. Maclean, N. Electron microscopy of a fission yeast, Schizosaccharomyces pombe. J. Bacteriol. 1964, 88, 1459-1466. [PubMed]

54. Vivas, N.; Vivas de Gaulejac, N.; Nonier, M.F.; Nedjma, M. Les phénomènes colloïdaux et l'interêt des lies dans l'élevage des vins rouges: Une nouvelle approche technologique et méthodologique. $2^{\circ}$ partie-Méthodes destinés aux élevages en cuves de grande capacité. Revue Française D'oenologie 2001, 190, $32-35$.

55. Vivas, N.; Vivas de Gaulejac, N.; Nonier, M.F.; Nedjma, M. Les phénomènes colloïdaux et l'interêt des lies dans l'élevage des vins rouges: Une nouvelle approche technologique et méthodologique. $1^{\circ}$ partie-Methodes traditionnelles d'élevage sur lie destinés aux vins en fûts. Revue Française D'oenologie 2001, 189, 33-38.

56. Pérez-Serradilla, J.A.; de Castro, M.D.L. Role of lees in wine production: A review. Food Chem. 2008, 111, 447-456. [CrossRef] [PubMed]

57. Lubbers, S.; Leger, B.; Charpentier, C.; Feuillat, M. Effet colloide-protecteur d'extraits de parois de levures sur la stabilité tartrique d'une solution hydro-alcoolique modele. J. Int. des Sci. la Vigne du Vin 1993, 27, $13-22$. [CrossRef]

58. Riou, V.; Vernhet, A.; Doco, T.; Moutounet, M. Aggregation of grape seed tannins in model wine-Effect of wine polysaccharides. Food Hydrocoll. 2002, 16, 17-23. [CrossRef]

59. Moine-Ledoux, V.; Dubourdieu, D. An invertase fragment responsible for improving the protein stability of dry white wines. J. Sci. Food Agric. 1999, 79, 537-543. [CrossRef]

60. Waters, E.J.; Pellerin, P.; Brillouet, J.-M. A Saccharomyces mannoprotein that protects wine from protein haze. Carbohydr. Polym. 1994, 23, 185-191. [CrossRef]

61. Vidal, S.; Williams, P.; Doco, T.; Moutounet, M.; Pellerin, P. The polysaccharides of red wine: Total fractionation and characterization. Carbohydr. Polym. 2003, 54, 439-447. [CrossRef]

62. Frankel, E.N.; German, J.B.; Kinsella, J.; Parks, E.; Kanner, J.E. Inhibition of oxidation of human low-density lipoprotein by phenolic substances in red wine. Lancet 1993, 341, 454-457. [CrossRef]

63. Salmon, J.M.; Fornairon-Bonnefond, C.; Mazauric, J.P. Interactions between Wine Lees and Polyphenols: Influence on Oxygen Consumption Capacity during Simulation of Wine Aging. J. Food Sci. 2002, 67, 1604-1609. [CrossRef]

64. Mazauric, J.-P.; Salmon, J.-M. Interactions between Yeast Lees and Wine Polyphenols during Simulation of Wine Aging: I. Analysis of Remnant Polyphenolic Compounds in the Resulting Wines. J. Agric. Food Chem. 2005, 53, 5647-5653. [CrossRef] [PubMed]

65. Mazauric, J.-P.; Salmon, J.-M. Interactions between Yeast Lees and Wine Polyphenols during Simulation of Wine Aging: II. Analysis of Desorbed Polyphenol Compounds from Yeast Lees. J. Agric. Food Chem. 2006, 54, 3876-3881. [CrossRef] [PubMed]

66. Domizio, P.; Liu, Y.; Bisson, L.F.; Barile, D. Cell wall polysaccharides released during the alcoholic fermentation by Schizosaccharomyces pombe and S. japonicas: Quantification and characterization. Food Microbiol. 2017, 61, 136-149. [CrossRef] [PubMed]

67. Romani, C.; Lencioni, L.; Gobbi, M.; Mannazzu, I.; Ciani, M.; Domizio, P. Schizosaccharomyces japonicus: A Polysaccharide-Overproducing Yeast to Be Used in Winemaking. Fermentation 2018, 4, 14. [CrossRef]

68. Benito, Á.; Calderón, F.; Palomero, F.; Benito, S. Combine use of selected Schizosaccharomyces pombe and Lachancea thermotolerans yeast strains as an alternative to the traditional malolactic fermentation in red wine production. Molecules 2015, 20, 9510-9523. [CrossRef] [PubMed] 
69. De Fatima, M.; Centeno, F.; Palacios, A. Desacidificación biológica de mosto a través de la inoculación de levadura Schizosaccharomyces pombe encapsulada como alternativa a la no producción de aminas biógenas. In Proceedings of the International Symposium of Microbiology and Food Safety in Wine "Microsafetywine", Vilafranca del Penedès, Spain, 20-21 November 2007.

70. Peinado, R.A.; Moreno, J.J.; Maestre, O.; Ortega, J.M.; Medina, M.; Mauricio, J.C. Gluconic acid consumption in wines by Schizosaccharomyces pombe and its effect on the concentrations of major volatile compounds and polyols. J. Agric. Food Chem. 2004, 52, 493-497. [CrossRef] [PubMed]

71. Peinado, R.A.; Mauricio, J.C.; Medina, M.; Moreno, J.J. Effect of Schizosaccharomyces pombe on aromatic compounds in dry sherry wines containing high levels of gluconic acid. J. Agric. Food Chem. 2004, 52, 4529-4534. [CrossRef] [PubMed]

72. Lubbers, M.W.; Rodriguez, S.B.; Honey, N.K.; Thornton, R.J. Purification and characterization of urease from Schizosaccharomyces pombe. Can. J. Microbiol. 1996, 42, 132-140. [CrossRef] [PubMed]

73. Uthurry, C.A.; Suárez-Lepe, J.A.; Lombardero, J.; García Del Hierro, J.R. Ethyl carbamate production by selected yeasts and lactic acid bacteria in red wine. Food Chem. 2006, 94, 262-270. [CrossRef]

74. Kulkarni, P.; Loira, I.; Morata, A.; Tesfaye, W.; González, M.C.; Suárez-Lepe, J.A. Use of non-Saccharomyces yeast strains coupled with ultrasound treatment as a novel technique to accelerate ageing on lees of red wines and its repercussion in sensorial parameters. LWT-Food Sci. Technol. 2015, 64, 1255-1262. [CrossRef]

75. Loira, I.; Vejarano, R.; Morata, A.; Ricardo-da-Silva, J.M.; Laureano, O.; González, M.C.; Suárez-Lepe, J.A. Effect of Saccharomyces strains on the quality of red wines aged on lees. Food Chem. 2013, 139, 1044-1051. [CrossRef] [PubMed]

76. Ivit, N.N.; Loira, I.; Morata, A.; Benito, S.; Palomero, F.; Suárez-Lepe, J.A. Making natural sparkling wines with non-Saccharomyces yeasts. Eur. Food Res. Technol. 2018, 244, 925-935. [CrossRef]

77. Wang, J.; Li, M.; Li, J.; Ma, T.; Han, S.; Morata, A.; Suárez Lepe, J.A. Biotechnology of ice wine production. In Advances in Biotechnology for Food Industry; Elsevier: New York, NY, USA, 2018; pp. 267-300.

(C) 2018 by the authors. Licensee MDPI, Basel, Switzerland. This article is an open access article distributed under the terms and conditions of the Creative Commons Attribution (CC BY) license (http:/ / creativecommons.org/licenses/by/4.0/). 